\title{
G \\ Memória de José Rodrigues Coura
}

\author{
por \\ Celso Ferreira Ramos Filho \\ Departamento de Doenças Infecciosas e Parasitárias, UFRJ \\ celso.ramosfilho@gmail.com
}

José Rodrigues Coura nasceu em Taperoá, no Cariri, praticamente no centro geodésico do Estado da Paraíba. Na ocasiáo, o município teria menos de 10 mil habitantes. Hoje tem cerca de 15.500, com um PIB per capita de R \$ 8.091,77, o que o coloca em $128^{a}$ posição entre os 223 municípios da Paraíba. Apenas 55\% dos imóveis têm esgotamento sanitário adequado. Tem 12 estabelecimentos de saúde, um eletrocardiógrafo, e nenhum aparelho de imagem. O seu IDH é baixo: 0,578. Imagine-se o que seria Taperoá, em 15 de junho de 1927.

O professor Coura foi alfabetizado na escola da irmã Cotinha, prosseguindo depois o estudo fundamental na escola de Seu Gui. Lá, foi colega de Ariano Suassuna: após o assassinato do pai, por razóes políticas, a família do futuro escritor tinha se mudado para Taperoá em 1933, onde ficou até 1937. Suassuna imortalizou a cidade, ao transformá-la no cenário tanto de seu Romance da Pedra do Reino quanto da peça O Auto da Compadecida.

Terminado o curso primário, Coura foi parao Ginásio Diocesanode Patos. Lá, a maisde cem quilômetros de Taperoá, ficou em regime de internato, mas em 1945 estava de volta à terra natal, onde resolve assumir a gerência da fazenda da família, que ele julgava fosse não improdutiva - mas mal administrada pelo pai; o único empreendimento profissional em que o professor Coura náo teve sucesso: $\mathrm{o}$ minifúndio era realmente improdutivo.

Em outras páginas, é contada a sua fuga de Campina Grande, em 1946, expropriando o valor da venda de 3 barris de manteiga, e o seu embarque, de supetáo, no caminhão do Joca "direto para o Rio de Janeiro". Mas, "direto para o Rio", o caminhão não foi: em Montes Claros, o Professor Coura tomou o trem da Central do Brasil, para o então Distrito Federal. 
É possível que ele nunca se tenha dado conta de que, do entroncamento em Corinto (por onde o trem obrigatoriamente transitou) saía o ramal de Pirapora, passando por Lassance, pouco mais de 70 quilômetros de trilhos. Por sua vez, a estrada Rio-Bahia estava sendo aberta, e quiçá dela o caminháo do Joca tenha percorrido algum trecho. A rodovia já foi apontada como responsável pela disseminação da esquistossomose no Sudeste, através da migração de trabalhadores, na diáspora nordestina - e é desnecessário mencionar a ligação histórica de Lassance com a Doença de Chagas. Assim, aquela viagem - que terá sido penosa mesmo para um adolescente de 19 anos - de certo modo prenuncia os dois grandes objetos de estudo de José Rodrigues Coura. O terceiro, a malária, veio depois; tivesse vindo antes, minha colaboração com ele teria sido maior, e mais profunda, e minha carreira, outra, talvez.

Seu emprego na Standard Oil permitiulhe aprender inglês e datilografia, e matricular-se no curso noturno do Colégio Frederico Ribeiro. Concluído o segundo grau em 1950, ingressa em 1952 na Faculdade Nacional de Medicina, da Universidade do Brasil, na Praia Vermelha.

Formou-se em dezembro de 1957, aos 30 anos, já entâo casado com sua colega de turma, Acadêmica Professora Léa Ferreira Camilo-Coura. Interessado em Cardiologia, fez em 1958 um curso de aperfeiçoamento no Serviço do Professor Luiz Decourt com os doutores Joáo e Bernardino Tranchesi, no Hospital das Clínicas da USP. Em seguida, e no mesmo ano, entrou para a Escola de Saúde do Exército. Permaneceu no Exército até 1962, quando deixou a força terrestre no posto de Capitáo Médico.

Em março de 1960 foi contratado como Instrutor de Ensino da entáo Cadeira de Clínica de Doenças Tropicais e Infectuosas, no saudoso Pavilhão Carlos Chagas. Segundo a Professora Léa Coura, o catedrático e chefe de serviço, Professor José Rodrigues da Silva lhe perguntou um dia se ela conhecia algum cardiologista, que pudesse ir trabalhar no PCC - ao que ela respondeu que sim, e que esse era o seu marido. $\mathrm{O}$ encontro com Rodrigues da Silva deu a Coura um exemplo, um modelo, e sua maior influência, como ele mesmo náo se cansava de dizer.

Em 1963 o Professor Coura recebeu uma bolsa do British Council, permanecendo em Londres até agosto de 1964, frequentando diversos hospitais, como o Hammersmith (então sede da Royal Postgraduate Medical School) e no (então) National Heart Hospital, próximo à famosa Harley Street. Esse foi um dos primeiros hospitais no mundo a ser construído especialmente para pesquisa, tratamento e treinamento pós-graduado em doenças cardiovasculares. 
Frequentava semanalmente as sessões do Royal Brompton Hospital, em Chelsea, (bairro cujos telhados foram celebrados na Última Elegia, de Vinicius de Moraes), e do Royal Free Hospital, então ainda em Gray's Inn Road, um dos primeiros hospitais de Londres a aceitar mulheres como alunas, e onde pontificava a Professora Dame Sheila Sherlock, maior autoridade em Hepatologia, em sua época.

Uma reflexão, para estes tempos de pandemias e falsificações. O Royal Free mantém uma unidade de segurança máxima para o tratamento de doenças causadas por germes de alta virulência, como o vírus Ebola, mas foi onde se criou a controvérsia sobre uma associação entre autismo e vacina tríplice viral, originada por um trabalho publicado no The Lancet por Andrew Wakefield, com dados forjados - trabalho posteriormente objeto de retratação pela revista; uma fraude que levou à consequente cassação do diploma médico de Wakefield.

Assim armado e equipado, submete-se em dezembro de 1965 a exame de LivreDocência na Cadeira de Clínica de Doenças Tropicais e Infectuosas da Faculdade de Medicina da Universidade Federal do Rio de Janeiro, defendendo a tese "Contribuição ao Estudo da Doença de Chagas no Estado da Guanabara”. Foi quando demonstrou a presença de triatomíneos naturalmente infectados por T. cruzi no bairro de Santa Teresa - sem doença humana: não bastava o a agente, o vetor e o hospedeiro. Faltavam condições sociais para uma endemia. Foi aprovado com distinção em todas as provas, obtendo os títulos de Livre-Docente e Doutor em Medicina pela UFRJ, e sendo promovido a Professor Adjunto.

Logo em fevereiro, obteve o $1^{\text {o }}$ lugar em concurso de títulos para Professor Titular contratado da Disciplina de Doenças Infecciosas e Parasitárias da Faculdade de Medicina da UFF. Tinha oito anos de formado. No Hospital Universitário Antônio Pedro organizou um modelar e moderno Serviço de Doenças Infecciosas, reformulou e modernizou o currículo da Disciplina de Doenças Infecciosas, e formou numerosos discípulos. Em 1970 fez concurso para o provimento efetivo daquela disciplina, sendo aprovado com nota 10 . Tinha 43 anos de idade.

José Rodrigues da Silva morreu precocemente, em 26 de maio de 1968, com 56 anos.

Lembro-me bem de quando vi pela primeira vez o Professor Coura. Foi há 53 anos, em junho de 1968, no anfiteatro da Farmacologia, no prédio da Praia Vermelha. Inesperadamente, o Professor Lauro Solero reúne a turma do Terceiro Ano, e diz que a aula daquela segunda-feira seria sobre 
Doença de Chagas, no lugar da programada. $\mathrm{Na}$ apresentaçáo que faz do Professor Coura, afirma que, antes de morrer, o Professor Rodrigues havia declarado que o seu substituto deveria ser ele. De fato, sendo o único Livre Docente e Doutor, o Professor Coura assumiu a Regência da Disciplina e a chefia do Serviço, no PCC.

Em 1971, o Diretor da Faculdade de Medicina, Professor Acadêmico José Leme Lopes propôs à Congregação da Faculdade de Medicina a transferência do Professor Coura da UFF para a UFRJ, o que foi aprovado por unanimidade. Neste ano, é criado o Departamento de Medicina Preventiva, do qual ele foi o primeiro chefe. Um ano antes, havia começado o Curso de Pós-Graduação stricto sensu em Doenças Infecciosas e Parasitárias da UFRJ, o primeiro curso da área médica credenciado no Brasil pelo Conselho Federal de Educação, e que comemorou 50 anos em 2020, sempre tendo conceito máximo pelo sistema CAPES/CNPq.

Com a inauguração do ansiado Hospital Universitário da UFRJ, em 1978, organizou e instalou o atual Serviço de Doenças Infecciosas, e foi ao mesmo tempo Diretor da Divisão de Saúde da Comunidade do novo hospital.

Não é nosso objetivo transcrever o Currículo Lattes de Coura: antes, é o de mostrar-lhes as dificuldades que enfrentou no começo da vida, o cuidado com que se preparou para os desafios que antepôs a si, e os êxitos que obteve. A sorte, que ele dizia ter, só bafeja a quem dela se coloca a sotavento. Mas devo lhes dizer que ele foi um dos maiores pesquisadores mundiais contemporâneos sobre a Doença de Chagas, e que o conhecimento que se tem da doença na Amazônia se deve principalmente a ele.

Também não posso deixar de dizer que ele tomou posse como Titular da Academia Nacional de Medicina em 16 de novembro de 1978, passando a ocupar a Cadeira de número 11, vaga pelo falecimento de Collares Moreira, tendo como patrono Antônio Austregésilo Rodrigues Lima, e sendo saudado por Clementino Fraga Filho.

Em 1979 foi convidado para a VicePresidência de Pesquisa da Fundação Oswaldo Cruz e Direçáo do Instituto Oswaldo Cruz, que aceitou com a condiçấo de não se afastar da UFRJ - o que terminou acontecendo em 1985, porém. Com justa razão, o Professor Coura tinha essa relação com o IOC como o coroamento de sua carreira; mas desconfio que o seu afastamento do Hospital Universitário se deveu à impossibilidade de manter lá a estrutura que tinha no PCC, o que não lhe permitia fazer o que mais gostava: trabalho de campo.

Há um triste episódio na vida do Professor Coura que me sinto compelido a 
revelar, episódio que muito o amargurou, e do qual poucos tenham talvez conhecimento. Embora não fosse politicamente ativo, nem expressasse publicamente opinióes a respeito, o Acadêmico Coura era um conservador. Já no Hospital Universitário Clementino Fraga Filho, alguns docentes da área de Saúde Coletiva começaram a disseminar o boato - a "fake news" - que ele era ou havia sido informante dos órgãos de repressão, durante o governo militar. Lembro-me de sua indignação quando alguns colegas da área de Doenças Infecciosas (dentre os quais eu não estava) o procuraram para saber se havia algum fundo de verdade no boato, o que o magoou profundamente, pela desconfiança que nele assim demonstravam. Creio mesmo que aquela campanha difamatória, afinal, tenha precipitado ou contribuído para sua saída da UFRJ. Episódio tanto mais vexatório e grave porque uma das líderes da campanha - senão a principal líder - era ou tinha sido sua amiga, devia a ele o emprego de professora no Departamento de Medicina Preventiva, frequentara a sua casa, privara da intimidade da família, companheira que fora de um amigo de toda a vida. Mais ainda, um de seus alunos prediletos, coestaduano, que também devia favores ao Professor, do mesmo modo era partícipe da trama.

Pode lhes parecer estranho que estas palavras estejam sendo ditas neste momento.
Mas é um aspecto da vida de José Rodrigues Coura que talvez seja conhecido apenas de meia dúzia de pessoas, os dois principais agentes da conspiração sendo já falecidos. Mas uso isto para lhes relatar dois episódios, que demonstram ser inverossímil a trama, que revelam o espírito democrático do Acadêmico Coura, e que certamente não constam dos relatos biográficos até hoje feitos sobre ele. Poucas pessoas sabem o que lhes relatarei agora.

No Congresso da UNE em Ibiúna, em outubro de 1968, diversos líderes estudantis foram presos, entre eles meu colega de turma, Reinaldo Felipe Nery Guimarães, de sobrenome ilustre em Manguinhos. Em 15 de dezembro do mesmo ano foi decretado o AI-5, desencadeando uma ampla perseguição pelo país. Reinaldo teve de deixar a casa dos pais e, até as coisas se acalmarem, no início do $4^{\circ}$ ano médico, se abrigou no Pavilhão Carlos Chagas, onde dormia todas as noites, com pleno conhecimento do Professor Coura.

$\mathrm{Na}$ década de 70, com a repressão no auge, a então aluna e depois deputada pelo PCB Lúcia Souto, com algumas passagens pelo Departamento de Ordem Política e Social, enfrentava problemas para a conclusão de seu curso médico, uma vez que, para os estágios, era necessária uma espécie de "nada consta" do DOPS, que ela não tinha como obter. Isto se resolveria com uma declaração 
de boa conduta, exarada por um professor e que foi obtida. Obtidas, aliás: duas. Mas foram recusadas pela polícia: era necessário constar que o signatário tinha conhecimento da condição de comunista da aluna, e que por ela e por seu comportamento se responsabilizava. José Rodrigues Coura fez e assinou a declaração, permitindo que Lúcia Souto se formasse em Medicina.

Este é o comportamento de um democrata, de um indivíduo tolerante, de um espírito aberto e esclarecido, que teve entre seus alunos, amigos e colaboradores alguns que assumiram posiçóes que seguramente não coincidiam com as dele, sem que a colaboração e a amizade sofressem qualquer percalço, embaraço ou impedimento.

Como diz a Professora Léa, "o Zè" teve muitos méritos - mas os teve por que para isso se preparou, para isso trabalhou, e muito: até que a doença não mais lhe permitisse fazê-lo.

Agradeço a Lúcia Souto, Felipe Guimarães e Léa Coura as informaçôes prestadas.

O Professor Coura se orgulhava de ter tido Rodrigues da Silva como mestre. Eu me orgulho de ter sido aluno de José Rodrigues Coura. 